\title{
A missional reformed refocus
}

\section{Book Title:}

Reformed means missional.

Following Jesus into the world

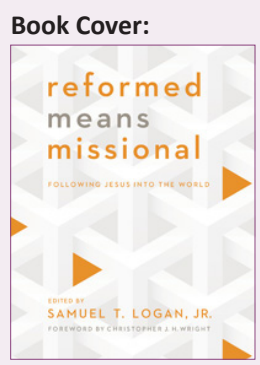

Author:

S.T. Logan, Jr (ed.)

ISSN:

978-1-938267-75-8

\section{Publisher:}

Greensboro: New Growth

Press, 2013, R243.52*

*Book price at time of review

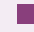

Review Title:

A missional reformed refocus

Reviewer:

Ignatius W. Ferreira ${ }^{1}$

\section{Affiliation:}

${ }^{1}$ Faculty of Theology,

North-West University,

Potchefstroom Campus,

South Africa

Email:

10322086@nwu.ac.za

Postal Address:

PO Box 674, Wingatepark

0153, South Africa

How to cite this book review:

Ferreira, I.W., 2014, 'A

missional reformed refocus',

In die Skriflig 48(1), Art.

\#1796, 2 pages. http://

dx.doi.org/10.4102/ids.

v48i1.1796

\section{Copyright:}

(C) 2014. The Authors.

Licensee: AOSIS

OpenJournals. This work

is licensed under the

Creative Commons

Attribution License.

\section{Read online:}

The treasure of our Reformed confessions was formulated in a time that is today commonly referred to as the time of Christendom. ${ }^{1}$ We search these writings in vain for an intentional missional theological expression that focuses on the non-believing world outside of Christendom. The reason may be the fact that these confessions were essentially intended as an urgent call to a deformed Christian church living within the cultural boundaries of Christendom. Today, however, the time of Christendom has passed. The content of our Reformed tradition is still foundational for the church of Jesus Christ, but it is now confronted with the near overwhelming reality of a non-Christian world - which is not somewhere in the fading distance of our planet, but has become a confronting reality in the context of our own everyday existence. The time has come for our Reformed confessions to be missionally refocused.

This is the reason for the origin of the book titled Reformed means missional. It is the result of an initiative of the World Reformed Fellowship (WRF). This is not a book in which Reformed thinkers are considering vague possibilities of careful action. This is a book in which Reformed servants have stepped over the threshold of the well known, and entered into the unknown turbulent world of our time. The subtitle of the book confirms their intentional commitment: 'Following Jesus into the world'. That is exactly the practical contribution that each of the authors is doing in their own ministry. It starts with an introductory orientation about the Biblical meaning of being a missional church. This is followed by a thorough discussion of the Reformed theologian Jonathan Edwards' missionary approach, wherein he emphasises the right relationship between Christians' Orthodox faith and their moral conduct. Another article in the first part of the book explains the missionary mandate of the book of Romans.

In the second part of the book, the intentional focus is to explore a practical missional ministry within the harsh reality of our broken world. It is clear that each of the authors struggled with several practical issues and they offer solutions to consider. They generously share their insight and practical knowledge with the reader. There is a section that focuses on how the issue of poverty and social injustice should be handled. The reality and challenges that the modern city presents to the church of Jesus Christ is also discussed, and a practical way for a missional focus on health issues in the modern city is explained. There is also an excellent article about a missional response to the global crisis of violence against women. The door of a very dark world, which is relatively close to all of us but of which most of us are blissfully unaware, is unlocked: do we really understand the extent of and the way in which sexual abuse of children should be handled? The magnitude of this problem is much bigger than we think.

There is also the reality of so-called 'diaspora churches' in our midst. The context of the New Testament church is once again a reality in our own time. What is the church called to do when it faces the diversity of the secularised world around us? How should the church of Jesus Christ approach the challenges of ministry to Muslims? An article in the book offers valuable insights. Do we know of the 'hidden Christians' in our world? How should we care for them? How should churches minister to the homosexual community in our midst? A wealth of practical ministry experience is shared with us. We are indeed privileged to sit at the feet of these servants of God.

The implications of a conscious decision to focus missionally on the world around us, is huge. This is the reason why there is a specific section that exclusively focuses on the critical challenge of an evangelical, Reformed and missional theology that must be (re)designed for the 21st century. We will not know what is lacking practically and theologically unless we intentionally and incarnationally start to cross our own comfort zones into the unknown and harsh reality of the world we live in. It will not be easy, but is imperative that it must be done. This is also the reason for a clear and timely call to the church and the academy to 'bridge the gap' and start working together in future. 
This book confronts my own beliefs and dramatically enhances my own ministry. To be Reformed is foundational to being the church of Jesus Christ - but something is still missing. An intentional, outward, missional focus is needed. We must follow Jesus Christ into the world (Heb 13:13-14).
Everyone who is serious about being Reformed should read and reread this book. However, not all is said and done - yet. This book only provides the introductory paragraphs of a Reformed theology that urgently needs to fill and supplement what has been lacking so far: a missional Reformed refocus. 